\title{
Revisiting The Certifying Role Of Financial Intermediaries On IPOS
}

Kyojik Song, Sungkyunkwan University, South Korea

Young-Soo Choi, Sungkyunkwan University, South Korea

Jong Eun Lee, Sungkyunkwan University, South Korea

\begin{abstract}
This paper re-examines the role of commercial banks, investment banks, and venture capitalists in monitoring and certifying the value of the firms that went public in the 2000s. We find that investment banks that have better reputations are associated with larger underpricing for venturecapital-backed IPOs, but not for non-venture-capital-backed IPOs. The partial adjustment phenomenon observed in Carter et al. (2001) exists only for venture-capital-backed IPOs. The presence of venture capital is inversely related to IPO underpricing only when venture capitalists certify small firms. We do not find that the presence of bank debt reduces IPO underpricing. In addition, we do not find any substitutive or complementary role between commercial banks and venture capitalists in certifying IPOs.
\end{abstract}

Keywords: Commercial Banks; Investment Banks; Venture Capitalists; Underpricing

\section{INTRODUCTION}

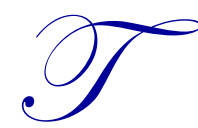

he certification and monitoring roles by financial intermediaries during the initial public offering (IPO) process have been extensively analyzed in the literature. ${ }^{1}$ In the event of an IPO, venture capitalists, commercial banks, and investment banks obtain information regarding the firm, certify that the information is accurate, and then convey this information to the market. Without ensuring that this information is accurate, these financial intermediaries can lose their reputations as credible financial intermediaries. The certification by these financial intermediaries should mitigate ex ante uncertainty of the IPO and consequently reduce necessary underpricing. However, an analysis of IPO underpricing during the 1990s reveals a positive relationship between an underwriter's reputation and IPO underpricing and an ambiguous role for venture capitalists in certifying the value of new issues. We have developed a few explanations for the opposite relationship between an investment bank's reputation and underpricing in the 1990s. This paper elucidates this issue using the sample from the 2000s.

The last decade has witnessed an explosion of venture capital investments. The role of venture capital is so important that some European corporations blame their lack of access to such financing as one of the reasons they lag behind the US. ${ }^{2}$ These arguments pose the question of what is the degree of substitution, or complementarity, between commercial banks and venture capitalists in providing resources during the initial stages of a firm's life and in reducing its cost of capital. This paper does not analyze the differences of financing roles between venture capitalists and commercial banks prior to the IPO; rather it analyzes the certification value of these financial intermediaries at the time of the IPO. Thus, this paper examines the possible complementarities among commercial banks, investment banks, and venture capitalists in certifying the value of firms when they first issue equity.

Evidence gathered from IPOs during the 1970s and 1980s suggests that the reputation of investment banks and auditors reduce ex ante uncertainty and, consequently, decrease the first day run-up (underpricing), measured as

\footnotetext{
${ }^{1}$ For example, Beatty and Ritter (1986), Carter and Manaster (1990), and Carter et al. (1998) find that investment banks can certify IPOs. Additionally, Megginson and Weiss (1991) find that the presence of venture capital reduces.

${ }^{2}$ See Black and Gilson (1998).
} 
the percentage change from the offering price to the closing price of the first trading date of an IPO. However, more recent studies of IPOs in the 1990s reported a positive relationship among the reputation of investment banks, presence of venture capital, and IPO underpricing. Benveniste and Spindt (1989) and Hanley (1993) predict a larger underpricing for IPOs that have a final offering price above the estimated price range in the prospectus. Using a sample of IPOs from 1990-1996, Carter et al. (2001) find that the negative relationship between investment bank's reputation and underpricing holds when the offering price is set between the high and low estimated prices, and a positive relationship holds when the offering price is above that of the estimated price in the prospectus. They argue that investment banks partially adjust the offering price for high demand offerings. Using the firms that went public in the 2000s, we find the phenomena to be consistent with Carter et al. (2001). When the sample is divided between venture-capital (VC) and non-venture-capital-backed IPOs, the positive relationship between the investment bank's reputation and underpricing exists only for VC-backed IPOs. No relationship between the underwriter's reputation and underpricing is found in the sample of non-VC-backed IPOs. Additionally, we find that the partial adjustment exists only for VC-backed IPOs. These results indicate that high-reputation underwriters underprice VC-backed IPOs with high demand more severely, which implies that the partial adjustment theory should be conditionalbased on the presence of venture capital.

Previous literature finds that the presence of bank debt tends to reduce IPO underpricing due to the certification and monitoring role of banks. ${ }^{3}$ However, the results in this paper indicate that during the period of our study there was no relationship between the presence of bank debt and IPO underpricing. Analysis of possible substitute effects among commercial debt, venture capital, and underwriter reputation shows no indication that banks reduce underpricing, even for non-venture-backed firms underwritten by low-reputation underwriters or smaller firms.

Megginson and Weiss (1991) find that venture capitalists reduce IPO underpricing by certifying and monitoring firms. However, in general, we find that the presence of venture capitalists is not significantly related to IPO underpricing even though we follow the sampling method of their paper. Nevertheless, we find that a significantly negative relationship exists between the presence of venture capitalists and IPO underpricing for those small firms that have substantial ex ante uncertainty and the potential for considerable informational asymmetries. Additionally, we do not find any substitutive or complementary relationship between banks and venture capitalists that affects IPO underpricing.

Interestingly, we find that the firms repaying bank debt using the proceeds from the IPO experience a low level of underpricing. Further examination reveals that the firms repaying bank debt are larger, less risky, and provide smaller growth opportunities, all of which explain the low level of underpricing.

The paper is organized in the following manner: Section 2 summarizes previous literature and proposes the hypothesis; Section 3 presents the data and methodology. Section 4 reports the empirical results, and Section 5 presents the conclusions.

\section{SUMMARY OF THE LITERATURE AND HYPOTHESIS}

Existing theoretical models have argued, and empirical literature has proven, that the role of financial intermediaries is to reduce asymmetries of information and lower the cost of capital for corporations.

First, investment banks, whose reputation is at stake, can certify the value of firms at the time of the IPO. Investment banks gain credible reputations by correctly certifying and effectively monitoring the quality of firms they underwrite. Evidence from IPOs during the 1970s and 1980s suggests that the reputations of investment banks and auditors reduce ex ante uncertainty, and consequently decrease the first day run-up (underpricing), measured as the percentage change from the offering price to the closing price of the first trading date of an IPO (Booth and Smith (1986), Beatty and Ritter (1986), Carter and Manaster (1990), and Carter et al. (1998)). However, more recent studies of IPOs report a positive relationship between the reputation of investment banks and underpricing. The study on IPOs by Carter et al. (2001) in the 1990s found that the negative relationship between investment

\footnotetext{
${ }^{3}$ See Slovin and Young (1990). 
bank's reputation and underpricing holds when the offering price is set between high and low estimated prices, and a positive relationship exists when the offering price is above the high estimated price in the prospectus. The authors argue that this larger underpricing is due to the stronger bargaining position of high-reputation investment banks in the context of a high demand of the issue. That is, investment banks partially adjust the offering of IPOs with high demand and accordingly underprice those IPOs more severely. Further, Benveniste and Spindt (1989) and Hanley (1993) suggest that those IPOs with an offering price above the highest estimated price in the prospectus should be underpriced more in order to compensate the investors that accurately transmit information regarding their demand.

This paper extends their analysis by considering possible substitutive effects of different monitors and the value of certification. The value of certification is more beneficial when firms experience greater asymmetries of information and there are no other monitors present. The effect of an underwriter's reputation on IPO underpricing may be less important when other financial intermediaries certify the IPOs.

The second group of financial intermediaries we consider is commercial banks. Diamond (1984) and Ramakrishnan and Thakor (1984) suggest that banks have comparative advantages in information gathering through the confidential relationships they have with their clients. As a result, banks are able to reduce adverse selection problems by certifying and monitoring firms, which then reduces the banks' cost of capital. Diamond (1984) suggests that banks are effective monitors, and the benefits of their monitoring are greater for firms that suffer more severe problems related to asymmetry of information. Several empirical studies support the value of the banking relationship. James (1987) finds positive abnormal returns to firms that announce bank credit agreements. Slovin, Johnson, and Glascock (1992) find that share price responses to bank loan initiation and renewal announcements are greater for small capitalization firms. They argue that large capitalization firms are well monitored and have a substantial reputation, and banks have no comparative advantage in the external financing process relative to public securities markets. However, small capitalization firms have greater information asymmetry, so they benefit from a banking relationship. Slovin, Sushka, and Hudson (1990) find that the presence of commercial bank debt mitigates the adverse selection problems associated with seasoned issuances of common stocks, consistent with the monitoring value of banks. Further, Johnson (1997) finds that bank reputation adds value to bank loan agreements. The study by Hull and Moellenberndt (1994) finds that seasoned common stock offering reduces bank debt. They find that common stock offerings whose proceeds are used to retire bank debt are associated with larger negative returns than those issues that retire non-bank debt. They suggest that the repayment of bank debts conveys more negative information to the market with potential agency problems by a shift in risk from bondholders to stockholders. However, Slovin, Sushka, and Hudson (1990) find that there is no significant relationship between the intention to repay bank debt and the announcement effects of seasoned common stock issues.

In the event of an IPO, Slovin and Young (1990) find that the presence of bank debt reduces the underpricing of an IPO. They find this evidence consistent with the function of banks that ameliorate asymmetries of information by providing valuable monitoring. Slovin and Young (1990) argue that both types of bank financing — bank loans and unused lines of credit -involve a banking relationship. As proposed by Beatty and Ritter (1986) and Rock (1986), the certification and monitoring created by this banking relationship should reduce underpricing by reducing ex ante uncertainty.

Third, this paper also examines the role of venture capital in monitoring IPOs. The benefits of the presence of venture capital during an IPO have been extensively documented. Barry, Muscarella, and Vetsuypens (1990) find that venture capitalists act as monitors by assuming concentrated equity positions within the firms. They hold important positions on the board of directors. They also show that venture capitalists tend to concentrate on a narrow set of industries in which they develop expertise. Specifically, they find that venture capitalists specialize in industries in which firms tend to have negative earnings at the time of the IPO. They also find that venture-capitalbacked IPOs are sold to more prestigious underwriters. The initial returns to venture-capital-backed IPOs are not statistically different from non-venture-capital-backed IPOs. However, Megginson and Weiss (1991) find that the presence of venture capital reduces IPO underpricing in a sample of firms during the period 1983-1987. Lerner (1994) finds that venture-capital-backed biotechnology firms go public near market peaks, thereby revealing the superior ability of venture capitalists to time IPOs. Gompers (1995) examines the role of venture capital in gathering information and monitoring firms and shows that the monitoring by venture capitalists is more beneficial when the firm suffers more adverse selection problems. 
The presence of venture capitalists in the firms during an IPO should reduce underpricing if venture capitalists can certify the firms. Venture capitalists hold large blocks of equity prior to and long after the offering date. Barry, Muscarella, and Vetsuypens (1990) report that in 58\% of the IPOs, the venture capitalists do not sell any shares during the offering and hold a mean equity share of $18 \%$ one year after the IPO. Thus, the presence of venture capitalists - who exert a monitoring role in the firms - is expected to reduce ex ante uncertainty and, consequently, IPO underpricing.

This paper analyzes the different characteristics of companies that have venture capital and bank debt in order to examine whether banks and venture capitalists are substitutes or complements in the monitoring and certification processes. Brav and Gompers (1997) find that venture-capital-backed IPOs outperform non-venturecapital-backed IPOs in the long term; they argue that the presence of venture capital can attract bank debt because venture capitalists certify the value of the company and ease access to bank debt. Therefore, venture capital is a complement to bank debt. The opposite argument can be based on the negative effects of bank debt (Sharpe (1990) and Rajan (1992)): venture capitalists do not want the interference of commercial banks in managing and extracting future profits from their firms. This paper illuminates this issue. We argue that the relationship between underpricing and underwriter reputation has a different effect on the samples of venture- and non-venture-backed IPOs, with the partial adjustment phenomenon existing only for VC-backed IPOs; this suggests that the presence of venture capital can be a determinant in explaining the positive or negative relationship between an underwriter's reputation and IPO underpricing. ${ }^{4}$

Based on the discussions above, we hypothesize in null form:

H: There is no effect of the relationship between underwriter and other financial intermediaries in certifying and monitoring the value of IPO firms on underpricing.

\section{SAMPLE SELECTION}

In order to test the effect of different financial intermediaries on IPO underpricing, following the sample selection criterion of Megginson and Weiss (1991), we match 210 venture-capital-backed firms with 210 nonventure-capital-backed firms in the same industry, as closely as possible, by offering size.

The data on IPOs are obtained from Securities Data Company (SDC), excluding unit issues, ADRs, reverse LBOs, and spinoffs. Offering price, SIC code, venture capital activity, lead underwriter, proceeds from the IPO, and offering date of the IPOs were also obtained from SDC. We eliminated IPOs of financial firms with SIC codes from 6000-6999. We matched the sample of venture-backed firms, as closely as possible, by proceeds from IPOs to nonventure-backed firms in the same three-digit SIC codes, as venture capital activity and the level of initial returns tend to be clustered by industry (Barry, Muscarella, and Vetsuypens (1990) and Lerner (1994)). If we did not find the matching firm on the basis of this criterion, these venture-backed firms were omitted from our sample. In this manner, we obtained 210 venture-capital-backed IPOs and 210 matching non-venture-capital-backed IPOs.

We found the prospectuses of 290 firms out of 420 in Lexis-Nexis and examined these prospectuses to obtain the financial data before the IPO, existence of bank debt, identity of the auditor, and use of the proceeds. Among the 290 firms in our final sample, 142 IPOs are venture-capital-backed, while 148 IPOs are not. From the audited financial statements of the year prior to the IPO found within the prospectuses, we obtained net earnings, earnings per share (EPS), total debt, long-term debt, and total assets. We recorded the IPOs with bank debt if the companies have "bank debt," a "line of credit," or both. ${ }^{5}$ Additionally, we classified the use of proceeds into eight

\footnotetext{
${ }^{4}$ Another group of financial intermediaries that certify the quality of a firm going public are public accounting firms. Titman and Trueman (1986) model the effect of the quality of public accountants on monitoring firms and argue that reputable auditors will maintain high reputation firms; the posterior monitoring of these firms should be associated with lower levels of monitoring. Using the classification by DeAngleo (1981) and Slovin, Sushka, and Hudson (1990), we find that less than 4\% of the firms in our sample have been audited by other auditors, rather than prestigious auditors. Given this small percentage, we have decided not to proceed with the analysis of the effect of auditor reputation on IPO underpricing.

${ }^{5}$ Some companies have unused line of credit. Then, we record the firms as they have bank debt.
} 
categories: 1) funding of working capital and general purpose; 2) repayment of bank debt; 3) investment in securities; 4) redemption of preferred stock; 5) repayment of private debt; 6) payment of accrued dividends; 7) funding of capital expenditures; and 8) obtainment of bank debt after the IPO. ${ }^{6}$

We used CRSP to obtain closing prices on the first trading day and returns during the 20 to 269 days after the IPOs. Because the initial returns from SDC have many missing observations and errors, we used the closing price from CRSP and offering price from SDC in order to calculate initial returns. Furthermore, we calculated the standard deviation of daily returns during the 20 to 269 trading days after the IPO in order to establish a proxy for the risk of the firm going public. ${ }^{7}$

Further, we proxied investment opportunities by the market-to-book ratio and R\&D expenditures, using the data collected from Research Insight on the ending date of the first fiscal year after the IPO. The ratio of the market value of assets to the book value (Market-to-Book ratio) is calculated by dividing the book value of liabilities and preferred stock plus the market value of common stock by the book value of assets. R\&D expenditure is the ratio of research and development expenditure to net sales.

\section{EMPIRICAL RESULTS}

\section{Summary statistics}

Table 1 presents the descriptive statistics for the sample of IPOs. The average (median) first day run-up is $17 \%$ (10\%), with a maximum of $152 \%$ and a minimum of $-17 \%$. The average (median) proceeds are $\$ 39.5$ million (\$32.40 million). The average standard deviation of returns during the first year after the offering date is $5 \%$, and the average underwriter's market share, which serves as proxy for the underwriter's reputation, is 0.03 . The mean number of use of proceeds is 2.19 , and the mean earnings per share (EPS) is $\$-0.27$. The average (median) ratio of long-term debt to total assets is $84 \%(67 \%)$. For the proxies of growth opportunities, the market-to-book ratio averages 3.53 on the ending date of first fiscal year, and the mean ratio of R\&D to net sales is $0.87 .^{8}$ Panel B shows that $73.72 \%$ of the companies in the sample have bank debts, and $57.87 \%$ of the companies that have bank debts use the proceeds to repay the existing debt.

Table 2 presents the test results of the difference between means and medians among the samples of venture- and non-venture-capital-backed IPOs. The last two columns in Panel A present the t-statistic for mean difference and z-statistics for nonparametric median tests, respectively. Venture-capital-backed IPOs experience one-day run-ups equal to $17 \%$, versus $18 \%$ for the sample of non-venture-backed IPOs; however, this difference is not statistically significant. This result is not consistent with the negative relationship observed by Megginson and Weiss (1991). Thus, venture- and non-venture-backed IPOs experience similar underpricing, which is not consistent with the value provided by venture capitalists in mitigating adverse selection problems of the IPOs. The mean (median) underwriter market's share (used as a proxy for underwriter reputation) for venture-capital-backed IPOs is 0.03 (0.02), and that for non-venture-capital-backed IPOs (median) is 0.03 (0.01), which is not statistically significant. This result is inconsistent with the findings of Barry, Muscarella, and Vetsuypens (1990), who find that venture-capital-backed IPOs are sold to more prestigious underwriters. Venture-capital-backed IPOs present statistically larger negative EPS than non-venture-capital-backed IPOs, which implies that the firms backed by venture capital go public at an earlier stage. In the subsample of venture-capital-backed IPOs, $73.10 \%$ have bank debt, not much different from the $74.32 \%$ of firms in the subsample of non-venture-capital-backed IPOs that have bank debt; $55.66 \%$ of the firms with venture capital repay bank debts, which is not much different from the 58.18\%

\footnotetext{
${ }^{6}$ Beatty and Ritter (1986) classify use of proceeds according to 32 categories; however, we cannot divide the use of proceeds into more than eight categories. Additionally, Beatty and Ritter include the firms issuing only secondary shares, but we do not include those firms.

${ }^{7}$ Investment banks tend to support the stock price for 20 days after the IPO, which distorts the true risk of the firms. Accordingly, we calculate standard deviation of daily returns for 250 trading days (approximately one year), starting 20 days after the IPO, in order to serve as proxy for risk of the firms.

${ }^{8}$ Research Insight records R\&D as not available for several firms in our sample; for such firms, we record R\&D expenditure as zero. Additionally, net sales are zero for several firms, which means that we cannot calculate the ratio of R\&D to net sales for these firms.
}

(C) 2012 The Clute Institute http://www.cluteinstitute.com/ 
of firms that repay bank debt in the sample of firms not backed by venture capital. In appearance, there is no relationship between venture financing and financing from banks at the time of the IPO. However, this statement needs to be assessed cautiously because it is necessary to have information on the proportion of bank debts compared to total debts across the two subsamples; additional research is required on this aspect of the study. Additionally, the data show that venture-capital-backed IPOs have larger growth opportunities in terms of the ratio of $R \& D$ expenditure to net sales.

In summary, there is no indication that venture- and non-venture-backed capital IPOs experience different levels of underpricing, which is not consistent with the certification and monitoring roles of venture capitalists. Venture-capital-backed IPOs have lower levels of earnings than non-venture-capital-backed IPOs, and there is some evidence that venture-capital-backed firms have greater growth opportunities.

In order to analyze the differences between IPOs with bank debt and those without bank debt, Table 3 reports the summary statistics for both subsamples. The average (median) underpricing for IPOs with bank debt is $18 \%(12 \%)$, and for the sample of firms that do not have bank debt, the average first day run-up is $14 \%(6 \%)$. The nonparametric median test reveals that the medians of the two subsamples are marginally different. The ex ante volatility of daily returns is larger for the sample of firms that do not have bank debt. The average standard deviation of returns is $5 \%$ for firms with bank debts and $6 \%$ for firms without bank debts, which means that banks lend money to less risky firms. The results also indicate that firms that have bank debt hire more prestigious underwriters than firms without bank debt, which suggests that investment banks with better reputations select firms that have been previously monitored by banks. Firms with bank debt also have higher EPS than firms that have not been previously monitored by banks. Firms with bank debt have a larger amount of total assets than firms without bank debt. The average (median) amount of assets prior to the offering is $\$ 45.11$ million ( $\$ 18.87$ million) for firms with bank debt and \$17.45 (\$7.51million) for firms without bank debt; the differences are statistically significant. Firms with bank debt have greater total debt to total assets and long-term debt to total assets; in addition, firms with bank debt have smaller growth opportunities.

In summary, these results indicate that firms with bank debt are larger, less risky, and have smaller growth opportunities than firms without bank debt. These results are consistent with Peterson and Rajan (1994), who argue that unlike banks, venture capitalists can extract rent after the IPO because they assume equity positions within the firm; however, banks cannot assume equity positions and are unable to finance high-risk projects. It is surprising that, in spite of the apparent greater value of assets and lower ex ante risk, as measured by the standard deviation of returns, the differences in the levels of underpricing are not statistically significant.

\section{Cross-sectional analysis}

This section presents a cross-sectional regression analysis to further analyze the roles of different financial intermediaries. Table 4 presents the cross-sectional regression analysis for the full sample in which the dependent variable is the first day run-up. The following are the independent variables in Model (1): OfferSize is the natural $\log$ of the proceeds raised in the IPO; Std is the standard deviation of daily returns from 20 to 269 days after the offer date; Underwriter is the underwriter's market share, which represents the underwriter's reputation; VC-backed is a qualitative variable that takes 1 if venture capital is present, and zero otherwise; \# of use of proceeds indicates the number of use of proceeds. 
Table 1. Descriptive Statistics

Panel A presents the summary statistics. Initial returns are calculated as the first-day closing price divided by the offering price minus one. Proceeds indicate the amount of money raised in the IPOs. Std of returns indicates the standard deviation of daily returns for 250 trading days from 20 days after the IPO. Underwriter's market shares are calculated year by year. EPS and assets indicate earnings per share and book value of total assets, respectively. Market-to-book is the ratio of the book value of liabilities and preferred stock plus the market value of common stock divided by the book value of assets. R\&D expenditure is the ratio of research and development expenditure to net sales.

Panel B presents the percentage of firms that have bank debt.

Panel A. Summary Statistics

\begin{tabular}{|c|c|c|c|c|c|c|}
\hline Variable & Mean & Median & Minimum & Maximum & Std. Dev. & $\mathbf{N}$ \\
\hline Initial return & 0.17 & 0.10 & -0.17 & 1.52 & 0.24 & 289 \\
\hline Proceeds (in million \$) & 39.50 & 32.45 & 4.40 & 289.50 & 32.88 & 290 \\
\hline Std of returns (day 20-269) & 0.05 & 0.05 & 0.01 & 0.14 & 0.02 & 290 \\
\hline Underwriter's market share & 0.03 & 0.02 & 0.00 & 0.11 & 0.03 & 290 \\
\hline Number of uses of proceeds & 2.19 & 2.00 & 1.00 & 4.00 & 0.87 & 290 \\
\hline EPS (\$) & -0.27 & 0.01 & -8.46 & 3.02 & 0.99 & 280 \\
\hline Assets (in million \$) & 37.59 & 15.43 & 0.13 & 614.79 & 70.63 & 287 \\
\hline Total debt-to-asset & 0.84 & 0.67 & 0.04 & 12.92 & 1.04 & 287 \\
\hline LT debt-to-asset & 0.27 & 0.09 & 0.00 & 6.38 & 0.54 & 287 \\
\hline Market-to-book & 3.49 & 2.89 & 0.88 & 14.82 & 2.20 & 241 \\
\hline R\&D expenditure & 0.87 & 0.05 & 0 & 71.95 & 5.34 & 235 \\
\hline
\end{tabular}

Panel B. Percentage of firms that have bank debt

Firms that have bank debt $\%$

Firms that repay bank debt among those that have bank debt $57.87 \%$ 
Table 2. VC-backed IPOs vs. Non-VC-backed IPOs

Panel A presents the difference in the means and medians of the variables between the two subsamples. Initial returns are calculated as the first-day closing price divided by the offering price minus one. Proceeds indicate the amount of money raised during the IPOs. Std of returns indicates the standard deviation of daily returns for 250 trading days from 20 days after the IPO. Underwriter's market shares are calculated year by year. EPS and assets indicate earnings per share and book value of total assets, respectively. Market-tobook is the ratio of the book value of liabilities and preferred stock plus the market value of common stock divided by the book value of assets. R\&D expenditure is the ratio of research and development expenditure to net sales.

Panel B presents the percentage of firms having bank debt.

Panel A. Comparative Statistics

\begin{tabular}{|c|c|c|c|c|c|c|c|c|}
\hline \multirow[b]{2}{*}{ Variable } & \multicolumn{3}{|c|}{ VC-backed IPOs } & \multicolumn{3}{|c|}{ Non-VC-backed IPOs } & \multicolumn{2}{|r|}{ Median } \\
\hline & Mean & Median & $\mathbf{N}$ & Mean & Median & $\mathbf{N}$ & t-test & Test \\
\hline Initial return & 0.17 & 0.09 & 141 & 0.18 & 0.12 & 148 & 0.37 & -1.36 \\
\hline Proceeds (in million \$) & 36.27 & 33.00 & 142 & 42.56 & 32.20 & 148 & $1.65^{*}$ & 0.23 \\
\hline Std of returns (day 20-269) & 0.05 & 0.05 & 142 & 0.05 & 0.05 & 148 & -0.10 & 1.17 \\
\hline Underwriter's market share & 0.03 & 0.02 & 142 & 0.03 & 0.01 & 148 & -1.31 & 0.94 \\
\hline EPS (\$) & -0.38 & -0.15 & 138 & -0.16 & 0.09 & 142 & $1.92 *$ & $-3.34 * * *$ \\
\hline Assets (in million \$) & 37.05 & 15.38 & 140 & 38.11 & 15.43 & 147 & 0.13 & 0.06 \\
\hline Total debt-to-asset & 0.74 & 0.60 & 140 & 0.94 & 0.71 & 147 & $1.67 *$ & -1.59 \\
\hline LT debt-to-asset & 0.22 & 0.08 & 140 & 0.31 & 0.12 & 147 & 1.41 & -0.41 \\
\hline Market-to-book & 3.67 & 2.92 & 120 & 3.30 & 2.85 & 121 & -1.32 & 0.84 \\
\hline$R \& D$ expenditure & 1.18 & 0.12 & 118 & 0.56 & 0 & 117 & -0.89 & $-4.27 * * *$ \\
\hline
\end{tabular}

*indicates that the means or medians of the two subsamples are significantly different at the $10 \%$ level

** indicates that the means or medians of the two subsamples are significantly different at the $5 \%$ level.

***indicates that the means or medians of the two subsamples are significantly different at the $1 \%$ level.

Panel B. Percentage of firms that have bank debt

\begin{tabular}{lcc}
\hline & VC & Non-VC \\
\hline Firms that have bank debt & $73.10 \%$ & $72 \%$ \\
Firms that repay bank debt among firms that have bank debt & $58.66 \%$ & $58.18 \%$ \\
\hline
\end{tabular}


Table 3. IPOs with bank debt vs. IPOs without bank debt

This table presents the difference in the means and medians between the two subsamples. Initial returns are calculated as the first-day closing price divided by the offering price minus one. Proceeds indicate the amount of money raised in the IPOs. Std of returns indicates the standard deviation of daily returns for 250 trading days from 20 days after the IPO. Underwriter's market shares are calculated year by year. EPS and assets indicate earnings per share and book value of total assets, respectively. Market-to-book is the ratio of the book value of liabilities and preferred stock plus the market value of common stock divided by the book value of assets. R\&D expenditure is the ratio of research and development expenditure to net sales.

\begin{tabular}{|c|c|c|c|c|c|c|c|c|}
\hline \multirow[b]{2}{*}{ Variable } & \multicolumn{3}{|c|}{ IPOs with bank debt } & \multicolumn{3}{|c|}{ IPOs w/o bank debt } & \multicolumn{2}{|r|}{ Median } \\
\hline & Mean & Median & $\mathbf{N}$ & Mean & Median & $\mathbf{N}$ & t-test & Test \\
\hline Initial return & 0.18 & 0.12 & 210 & 0.14 & 0.06 & 79 & -1.40 & $-1.94 *$ \\
\hline Proceeds (in million \$) & 40.91 & 33.00 & 211 & 34.82 & 27.60 & 79 & -1.30 & -1.45 \\
\hline Std of returns (day 20-269) & 0.05 & 0.05 & 211 & 0.06 & 0.05 & 79 & $3.56 * * *$ & $3.82 * * *$ \\
\hline Underwriter's market share & 0.03 & 0.02 & 211 & 0.02 & 0.02 & 79 & $-2.16 * *$ & -0.93 \\
\hline EPS $(\$)$ & -0.18 & 0.05 & 202 & -0.49 & -0.27 & 78 & $-2.53 * *$ & $-4.79 * * *$ \\
\hline Assets (in million \$) & 45.11 & 18.87 & 209 & 17.45 & 7.51 & 78 & $-3.90 * * *$ & $-3.94 * * *$ \\
\hline Total debt-to-asset & 0.79 & 0.69 & 209 & 0.96 & 0.55 & 78 & 0.91 & -1.55 \\
\hline LT debt-to-asset & 0.30 & 0.15 & 209 & 0.20 & 0.04 & 78 & -1.26 & $-3.14 * * *$ \\
\hline Market-to-book & 3.37 & 2.80 & 181 & 3.81 & 3.42 & 60 & 1.40 & $2.12 *$ \\
\hline R\&D expenditure & 0.54 & 0.01 & 179 & 1.02 & 0.30 & 56 & $1.72 *$ & $4.62 * * *$ \\
\hline
\end{tabular}

*indicates that the means or medians of the two subsamples are significantly different at the $10 \%$ level.

** indicates that the means or medians of the two subsamples are significantly different at the $5 \%$ level.

***indicates that the means medians of the two subsamples are significantly different at the $1 \%$ level. 
The coefficient for the variable OfferSize is 0.05 (t-statistic of 2.10), which is statistically significant and implies that larger IPOs are associated with higher underpricing. This result is contrary to the results suggested by the analysis of IPO underpricing in the 1970s and 1980s. The coefficient for the variable Std is 1.50 (t-statistic of 1.74); this is marginally significant and indicates that, ceteris paribus, an increase in the standard deviation of returns increases the level of underpricing, which is consistent with higher levels of compensation for investors for riskier IPOs. The level of underwriter reputation is positively correlated to underpricing. The coefficient for the variable Underwriter is 1.08 (t-statistic equals to 1.95), which is consistent with the findings by Carter et al. (2001), who studied IPOs in the 1990s; this result contrasts with the negative relationship between underwriter reputation and underpricing observed in the 1970s and 1980s. Carter et al. (2001) found that the positive relationship between underwriter reputation and underpricing occurs in those issues in which the final offering price is above the highest estimated price. They suggest that this relationship is due to the stronger bargaining position of high reputation investment banks within the context of a high demand of the issue. The coefficient for the variable VC-backed is 0.01 (t-statistic of -0.53) and is not significant. The lack of significance of this variable contrasts with the findings by Megginson and Weiss (1991). The coefficient on the number of use of proceeds is negative and not significant, which is not consistent with the findings of Beatty and Ritter (1986), in which they find a positive relationship between the number of use of proceeds and IPO underpricing. ${ }^{9}$ Nevertheless, Slovin and Young (1990) find that the relationship is insignificantly positive.

In summary, there is no indication that the monitoring role of investment banks and venture capitalists reduces IPO underpricing; this result is in contrast to the theories that suggest that monitoring and certification by these financial intermediaries reduces the ex ante risk of the issue.

Model (2) includes the presence of bank debt to the previous regression. The variable BankDebt is a qualitative variable that takes the value of 1 if the firm has bank debt and zero otherwise. The coefficient of the variable BankDebt is 0.03 (t-statistic of 0.79). Thus, there is no indication that the presence of bank debt reduces underpricing by monitoring and certifying the value of the firm. The presence of bank debt does not affect underpricing, which is in contrast to the findings of Slovin and Young (1990) who studied a sample of IPOs that went public from 1980 through 1984; however, they used the sample of IPOs with an offer price of $\$ 10$ or less because firms with a small offering size may have substantial ex ante uncertainty and potential for considerable informational asymmetries. However, the sample of this paper has a much larger offering size, which indicates that the presence of bank debt does not reduce ex ante uncertainty of the issue and no extra compensation to investors is necessary to reward higher levels of risk. Additionally, Model (2) includes the variable VC*BankDebt, a qualitative variable that takes the value of 1 if the firm has bank debt and venture capital and zero otherwise. The coefficient of VC-backed is -0.01 (t-statistic of -0.35), that for the variable BankDebt is 0.03 (t-statistic of 0.79), and that for the variable $\mathrm{VC} * \mathrm{BankDebt}$ is -0.06 (t-statistic of -0.06). These results indicate that the presence of both types of financial intermediaries - venture capitalists and banks - does not have an impact on IPO underpricing, and the two financial intermediaries play no substitutive or complementary role in certifying or monitoring the firms.

Model (3) includes the qualitative variable Repay that takes the value of 1 if the company repays bank debt using the proceeds from the IPO, and zero if the firm does not have bank debt or if it has bank debt and maintains it. The coefficient for the variable Repay is -0.05 (t-statistic of -1.92). Model (5) shows the regression result for the subsample after the firms without bank debt are omitted. The coefficient of variable Repay is negative and more significant compared to Model (3). This result consolidates the negative relationship between repayment of bank debt and IPO underpricing. In contrast to the theories that suggest that banks monitor and certify the value of the firm, these results indicate that repaying the bank debt decreases IPO underpricing. Although we do not have a convincing explanation for this observation, we will attempt to explain it later

\footnotetext{
${ }^{9}$ This result should be interpreted with caution. For our sample, the number of use of proceeds is positively related to repayment of bank debt, which means that the firms repaying bank debt tend to have a larger number of use of proceeds. Model 3 shows that the coefficient on repayment of bank debt is significantly negative, which is why we observe the insignificantly negative coefficient on the number of use of proceeds. Additionally, our classification for use of proceeds is different from that of Beatty and Ritter (1986). See Footnote 6.
} 
Table 4. Regression result for the entire sample

The dependent variable is the initial return. OfferSize is the natural log of proceeds raised in the IPO. Std indicates the standard deviation of daily returns for 250 trading from 20 days after the IPO, and Underwriter indicates underwriter's market share. VCbacked is 1 for venture-capital-backed IPO and 0 otherwise. BankDebt is 1 for IPOs with bank debt and 0 otherwise. VC*BankDebt is a qualitative variable that takes the value of 1 if the firm has bank debt and venture capital and 0 otherwise. \# Use of proceeds indicates the natural log of number of use of proceeds plus 1 . Repay is a qualitative variable that takes unity for IPOs repaying the bank debt using the proceeds from IPO. PrivateRepay is a qualitative variable that takes unity for IPOs repaying private debt using the proceeds from IPO.

\begin{tabular}{|c|c|c|c|c|c|}
\hline & Model 1 & Model 2 & Model 3 & Model 4 & Model 5 a) \\
\hline \multirow[t]{2}{*}{ Intercept } & $-0.76^{*}$ & $-0.84^{*}$ & $-0.77 *$ & $-0.81^{*}$ & -0.86 \\
\hline & $(-1.68)$ & $(-1.85)$ & $(-1.71)$ & $(-1.78)$ & $(-1.53)$ \\
\hline \multirow[t]{2}{*}{ OfferSize } & $0.05 * *$ & $0.05 * *$ & $0.05 * *$ & $0.05 * *$ & $0.05^{*}$ \\
\hline & $(2.10)$ & $(2.00)$ & $(2.00)$ & $(2.02)$ & $(1.80)$ \\
\hline \multirow[t]{2}{*}{ Std (day 20-269) } & $1.50 *$ & $1.64 *$ & 1.25 & $1.54 *$ & 1.56 \\
\hline & $(1.74)$ & (1.87) & $(1.42)$ & $(1.78)$ & (1.38) \\
\hline \multirow[t]{2}{*}{ Underwriter } & $1.08 *$ & $1.12 * *$ & $1.14 * *$ & $1.14 * *$ & $1.09 *$ \\
\hline & (1.95) & $(2.02)$ & $(2.07)$ & $(2.06)$ & $(1.78)$ \\
\hline \multirow[t]{2}{*}{ VC-backed } & -0.01 & -0.01 & -0.01 & -0.01 & 0.01 \\
\hline & $(-0.53)$ & $(-0.35)$ & $(-0.41)$ & $(-0.53)$ & $(0.04)$ \\
\hline \# Use of proceeds & $\begin{array}{c}-0.08 \\
(-1.60)\end{array}$ & & & & \\
\hline BankDebt & & $\begin{array}{c}0.03 \\
(0.79)\end{array}$ & & & \\
\hline VC*BankDebt & & $\begin{array}{c}-0.06 \\
(-1.48)\end{array}$ & & & \\
\hline Repay & & & $\begin{array}{c}-0.05 * \\
(-1.92)\end{array}$ & & $\begin{array}{l}-0.08 * * \\
(-2.54)\end{array}$ \\
\hline PrivateRepay & & & & $\begin{array}{l}(-0.03) \\
(-1.07)\end{array}$ & \\
\hline R-square & 0.06 & 0.05 & 0.06 & 0.05 & 0.09 \\
\hline $\mathbf{N}$ & 289 & 289 & 289 & 289 & 215 \\
\hline
\end{tabular}

a) In Model 5, we exclude the firms without bank debt, which decreases the sample size to 215 .

The numbers given in parentheses are t-statistics.

*indicates that the coefficient is significantly different from 0 at the $10 \%$ level.

** indicates that the coefficient is significantly different from 0 at the $5 \%$ level.

Model (4) includes the qualitative variable PrivateRepay, which takes the value of 1 if the firm uses the proceeds to repay private debt and zero otherwise. The coefficient for the variable PrivateRepay is -0.03 (t-statistic -1.07 , which is not statistically significant. This result indicates that the repayment of private non-bank debt does not affect underpricing, contrary to the effect of bank debt repayment.

The different characteristics of venture- and non-venture-capital-backed IPOs reported on Table 2 suggest the need for a separate study of both subsamples. Table 5 presents the regression results for the sample of venturebacked IPOs. The results of Models (1) to (4) indicate that the variables offering size and underwriter market share are positively and strongly correlated with the underpricing, which is consistent with the results in the overall sample. Model (2) includes the variable BankDebt, which shows that the presence of bank debt does not have any effect on the IPOs that are backed by venture capital. Model (3) includes the variable Repay and the coefficient of this variable is -0.05 (t-statistic of -1.15 ), which is not significant. The insignificance of the variable Repay contrasts with the significantly negative coefficient in the overall sample. In the overall sample, we suggest that the negative coefficient for this variable might be indication of less risk of the firms repaying bank debt. The reason that the repayment of bank debt is not related to IPO underpricing for this subsample is not clear. Venture capitalists actively monitor firms and may have more information than banks; therefore, the marginal benefits and marginal costs from a banking relationship may be smaller for firms with venture financing because venture capitalists can monitor and certify the firms. Accordingly, repaying or maintaining bank debt does not have much impact on the 
value of the firm for venture-capital-backed IPOs. This may explain why we observe that the repayment of bank debt is not related to IPO underpricing in the subsample of venture-capital-backed IPOs.

Finally, Model (4) includes the variable PrivateRepay. The coefficient for the variable PrivateRepay is not statistically significant; thus, the use of proceeds to repay private debt does not affect IPO underpricing and is consistent with the results of the overall sample.

Overall, the results for the sample of venture-capital-backed IPOs indicate that the offering size and the underwriter's reputation have a strongly positive effect on IPO underpricing. The results for this subsample are not consistent with the theory of the certification and monitoring role of investment banks.

Table 6 presents the results of the regression for the subsample of non-venture-backed IPOs. Model (1) includes the following variables: OfferSize, Std, Underwriter, and \# Use of Proceeds. None of these variables is statistically significant, which contrasts with the positive and significant sign of OfferSize and Underwriter in the VC-backed IPOs sample. The insignificance of these variables for the sample of non-VC-backed IPOs indicates that the presence of venture capital might explain the positive sign of these variables, which is found in more recent studies of IPO underpricing.

Model (2) includes the qualitative variable BankDebt, which is not significant and is consistent with the overall sample and the sample of venture-backed IPOs. The presence of bank debt does not reduce underpricing, as would be expected given the role banks have as certifiers and monitors of the firm. Model (3) includes the variable Repay, which has a coefficient equal to -0.06 (t-statistic of -1.82) and is statistically significant. The negative coefficient of this variable is not consistent with the role of bank debt in reducing ex ante uncertainty of the issue, which may be explained if firms that repay bank debt are less risky. Finally, Model (4) includes the variable, PrivateRepay, which is not statistically significant.

Overall, the results of the regression analysis are not consistent with the role of banks, venture capitalists, and investment banks in certifying the value of the firm or in reducing ex ante uncertainty of the IPO. The difference in the significance of Underwriter and OfferSize variables in the samples of venture and non-venture backed IPOs suggests that the presence of venture capital may be a factor in explaining the positive sign of these variables, as observed in the 1990s. At the time of writing this paper, the authors are acquainted only with the working paper by Carter et al., (2001), which provides an explanation of the positive correlation between underwriter reputation and underpricing; this study shows that a positive relationship exists only for the portion of their sample in which the offer price is set above the high estimated offer price as filed with the preliminary prospectus. Our results suggest that the positive relationship between an underwriter's reputation and IPO underpricing is conditional— based on the presence of venture capital.

In order to further examine the relationship between underpricing and the role of financial intermediaries, we include several interaction terms in the regression presented in Table 7. Model (1) includes the interaction term between the dummy variable for IPOs with the offer price above the high estimated price and underwriter's market share. The coefficient for the interaction term is strongly positive. Additionally, we divide the sample into IPOs with offer price above, within, and below the estimated price range in unreported regression. We find that the positive relationship between underpricing and underwriter's market share exists only for IPOs with an offer price that is above the estimated price range. These results are consistent with the findings of Carter et al. (2001), who argue that high-reputation underwriters underprice the high demand offering more severely through the use of superior bargaining strategies.

Model (2) includes the interaction term between the dummy variable for VC-backed IPOs and underwriter's market share. The coefficient for the interaction term is strongly positive, which is consistent with the results in Tables 5 and 6. Additionally, we divide the sample into six subsamples on the basis of the presence of venture capital and an offer price above, within, and below the estimated price range in unreported regression. We find that the positive relationship between underpricing and underwriter's market share exists only for VC-backed IPOs with an offer price above the estimated price range, which indicates that high-reputation underwriters underprice VC-backed IPOs with high demand more severely. 
Table 5. Regression result for VC-backed IPOs

The dependent variable is the initial return. OfferSize is the natural log of proceeds raised in the IPO. Std indicates the standard deviation of daily returns for 250 trading day from 20 days after the IPO, and Underwriter indicates underwriter's market share. \# Use of proceeds indicates natural $\log$ of number of use of proceeds plus 1 . BankDebt is 1 for IPOs with bank debt and 0 otherwise. Repay is a qualitative variable that takes the value of 1 for IPOs repaying bank debt. PrivateRepay is a qualitative variable that takes the value 1 for IPOs repaying private debt.

\begin{tabular}{|c|c|c|c|c|}
\hline 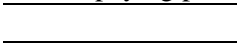 & Model 1 & Model 2 & Model 3 & Model 4 \\
\hline Intercept & $\begin{array}{l}-2.45^{* * *} \\
(-3.17)\end{array}$ & $\begin{array}{l}-2.52 * * * \\
(-3.25)\end{array}$ & $\begin{array}{l}-2.44 * * * \\
(-3.15)\end{array}$ & $\begin{array}{l}-2.53 * * * \\
(-3.28)\end{array}$ \\
\hline OfferSize & $\begin{array}{l}0.15^{* * * *} \\
(3.48)\end{array}$ & $\begin{array}{l}0.15^{* * * *} \\
(3.39)\end{array}$ & $\begin{array}{l}0.15^{* * * *} \\
(3.37)\end{array}$ & $\begin{array}{l}0.15^{* * * *} \\
(3.46)\end{array}$ \\
\hline Std & $\begin{array}{c}1.08 \\
(0.77)\end{array}$ & $\begin{array}{c}1.28 \\
(0.88)\end{array}$ & $\begin{array}{c}0.75 \\
(0.51)\end{array}$ & $\begin{array}{c}1.05 \\
(0.75)\end{array}$ \\
\hline Underwriter & $\begin{array}{l}1.82 * * \\
(2.43)\end{array}$ & $\begin{array}{l}1.88 * * \\
(2.47)\end{array}$ & $\begin{array}{l}1.93 * * \\
(2.58)\end{array}$ & $\begin{array}{l}1.90 * * \\
(2.53)\end{array}$ \\
\hline \# Use of proceeds & $\begin{array}{l}-0.10 \\
(-1.44)\end{array}$ & & & \\
\hline BankDebt & & $\begin{array}{c}0.02 \\
(0.34)\end{array}$ & & \\
\hline Repay & & & $\begin{array}{c}-0.05 \\
(-1.15)\end{array}$ & \\
\hline PrivateRepay & & & & $\begin{array}{c}-0.05 \\
(-1.09) \\
\end{array}$ \\
\hline R-square & 0.18 & 0.18 & 0.19 & 0.19 \\
\hline$\overline{\mathbf{N}}$ & 142 & 142 & 142 & 142 \\
\hline
\end{tabular}

The numbers given in parentheses are t-statistics.

*indicates that the coefficient is significantly different from 0 at the $10 \%$ level.

** indicates that the coefficient is significantly different from 0 at the $5 \%$ level.

$* * *$ indicates that the coefficient is significantly different from 0 at the $1 \%$ level.

Table 6. Regression result for Non-VC-backed IPOs

The dependent variable is the initial return. OfferSize is the natural log of proceeds raised in the IPO. Std indicates the standard deviation of daily returns for 250 trading day from 20 days after IPO, and Underwriter indicates underwriter's market share. \# Use of proceeds indicates the natural log of number of use of proceeds plus 1. BankDebt is 1 for IPOs with bank debt and 0 otherwise. Repay is a qualitative variable that takes the value 1 for IPOs repaying bank debt. PrivateRepay is a qualitative variable that takes the value 1 for IPOs repaying private debt.

\begin{tabular}{|c|c|c|c|c|}
\hline & Model 1 & Model 2 & Model 3 & Model 4 \\
\hline Intercept & $\begin{array}{c}-0.13 \\
(-0.25)\end{array}$ & $\begin{array}{c}-0.19 \\
(-0.35)\end{array}$ & $\begin{array}{c}-0.15 \\
(-0.28)\end{array}$ & $\begin{array}{c}-0.15 \\
(-0.29)\end{array}$ \\
\hline OfferSize & $\begin{array}{c}0.02 \\
(0.59)\end{array}$ & $\begin{array}{c}0.02 \\
(0.53)\end{array}$ & $\begin{array}{c}0.02 \\
(0.56)\end{array}$ & $\begin{array}{c}0.02 \\
(0.51)\end{array}$ \\
\hline Std & $\begin{array}{c}1.56 \\
(1.52)\end{array}$ & $\begin{array}{c}1.59 \\
(1.54)\end{array}$ & $\begin{array}{c}1.34 \\
(1.31)\end{array}$ & $\begin{array}{c}1.63 \\
(1.59)\end{array}$ \\
\hline Underwriter & $\begin{array}{l}-0.11 \\
(-0.14)\end{array}$ & $\begin{array}{c}-0.06 \\
(-0.08)\end{array}$ & $\begin{array}{c}-0.10 \\
(-0.13)\end{array}$ & $\begin{array}{l}-0.05 \\
(-0.07)\end{array}$ \\
\hline \# Use of Proceeds & $\begin{array}{c}-0.06 \\
(-0.93)\end{array}$ & & & \\
\hline BankDebt & & $\begin{array}{c}0.01 \\
(0.32)\end{array}$ & & \\
\hline Repay & & & $\begin{array}{l}-0.06^{*} \\
(-1.82)\end{array}$ & \\
\hline PrivateRepay & & & & $\begin{array}{c}-0.04 \\
(-0.96)\end{array}$ \\
\hline R-square & 0.02 & 0.02 & 0.04 & 0.02 \\
\hline $\mathbf{N}$ & 147 & 147 & 147 & 147 \\
\hline
\end{tabular}

The numbers given in parentheses are t-statistics.

*indicates that the coefficient is significantly different from 0 at the $10 \%$ level.

** indicates that the coefficient is significantly different from 0 at the $5 \%$ level.

***indicates that the coefficient is significantly different from 0 at the $1 \%$ level. 
Slovin and Young (1990) examine small IPOs with an offer price of \$10 or less because small firms may experience more adverse selection problems. In order to investigate the effect banking relationships have on smaller IPOs, Model (4) includes the interaction term between the dummy variable for presence of bank debt and the dummy variable for IPOs with below-median book assets. The coefficient for the interaction term is negative but insignificant, which indicates that bank debt does not affect underpricing, even for smaller firms. Model (3) includes the interaction term between the dummy variable for the presence of venture capital and the dummy variable for IPOs with below-median book assets. The coefficient for the interaction term is significantly negative, which indicates that the presence of venture capital mitigates the asymmetries of information that affect smaller firms.

The multivariate regression results discussed in the previous subsection reveal that repayment of bank debt is related to less underpricing. If firms repay their bank debt using the proceeds from the IPO, they may cancel their relationship with banks; however, an examination of financial statements from the ending date of the first fiscal year reveals that most firms that repaid their bank debt still maintained some form of a banking relationship, such as a line of credit. Why the repayment of bank debt is related to less underpricing is not clear. In order to find a possible explanation, we compare the characteristics of firms that repaid their bank debt with those that maintained bank debt and those without bank debt in Table $8 .^{10}$ The book value of assets, EPS, ROA, Market-to-Book, R\&D, total debtto-total asset, and long-term debt-to-assets were obtained from the ending date of the first fiscal year after the IPO.

Table 8 shows that firms that repay bank debt have a larger book value of assets and a smaller standard deviation of daily returns during and after the IPO, which implies that such firms are less risky as compared to firms that maintain bank debt and firms without bank debt. The profitability measures, EPS and ROA, show that the firms that repay bank debt are more profitable during each year. As for growth opportunities, the firms that repay bank debt have a smaller Market-to-Book and R\&D expenditure, which means they have smaller growth opportunities. Additionally, firms that repay bank debt have higher leverage ratios (total debt-to-assets and long-term debt-toassets), which is consistent with the view that those firms that are more well-established and less risky can maintain a larger leverage. The results reveal that the firms that repay bank debt are larger firms with less risk and are more profitable. Since such firms are less risky and have smaller growth opportunities, they have fewer asymmetries of information, which explains why the firms that repay bank debt experience less underpricing. ${ }^{11}$

\footnotetext{
${ }^{10}$ Additionally, we compare the firms that repay bank debt with the firms that maintain bank debt, after we exclude the firms without bank debt. Since the result is similar, we include the firms without bank debt in order to maintain a larger sample size.

${ }^{11}$ In the prospectuses, firms tell investors that they intend to repay bank debt using the proceeds from the IPO; however, there is a possibility that they will not repay their bank debt. In order to examine this possibility, we check the difference in leverage ratios (total debt-to-assets; long-term debt-to-assets) before and after IPO for two subsamples in Table 8. The leverage ratios for the subsamples are reduced due to equity issuance; however, the reduction of leverage ratios is significantly greater for the firms repaying bank debt, even though the offering size is similar in the two subsamples, which indicates that the firms that intended to repay their bank debt actually did.
} 
Table 7. Regression result for the entire sample

The dependent variable is the initial return. OfferSize is the natural log of proceeds raised in the IPO. Std indicates the standard deviation of daily returns for 250 trading from 20 days after IPO, and Underwriter indicates underwriter's market share. VCbacked is 1 for venture-capital-backed IPOs, and 0 otherwise. BankDebt is 1 for IPOs with bank debt and 0 otherwise. Above*underwriter is the interaction term between the dummy for IPOs with an offer price above the filing price range and underwriter's market share. VC*underwriter is the interaction term between dummy for VC-backed IPOs and underwriter's market share. VC*small firm is the interaction term between dummy for VC-backed IPOs and dummy for the firms with book assets below the median. BankDebt*small firm is the interaction term between dummy for IPOs with bank debt and dummy for the firms with book assets below median.

\begin{tabular}{|c|c|c|c|c|}
\hline & Model 1 & Model 2 & Model 3 & Model 4 \\
\hline \multirow[t]{2}{*}{ Intercept } & -0.63 & $-1.11 * *$ & $-0.91 * *$ & $-0.95 * *$ \\
\hline & $(-1.50)$ & $(-2.47)$ & $(-2.01)$ & $(-2.08)$ \\
\hline \multirow[t]{2}{*}{ OfferSize } & 0.04 & $0.07 * * *$ & $0.05 * *$ & $0.06^{* *}$ \\
\hline & $(1.59)$ & $(2.73)$ & $(2.12)$ & $(2.19)$ \\
\hline \multirow[t]{2}{*}{ Std } & $1.88 * *$ & $1.71 *$ & $2.20 * *$ & 2.05 \\
\hline & $(2.29)$ & $(1.95)$ & $(2.47)$ & $(2.25)$ \\
\hline \multirow[t]{2}{*}{ Underwriter } & -0.25 & -0.85 & 0.87 & $0.94 *$ \\
\hline & $(-0.46)$ & $(-1.10)$ & $(1.58)$ & $(1.70)$ \\
\hline \multirow{2}{*}{ VC-backed } & -0.01 & $-0.10 * *$ & 0.01 & -0.02 \\
\hline & $(-0.03)$ & $(-2.69)$ & $(0.30)$ & $(-0.56)$ \\
\hline \multirow[t]{2}{*}{ BankDebt } & $0.05 *$ & 0.03 & 0.03 & 0.05 \\
\hline & $(1.67)$ & $(1.03)$ & $(1.07)$ & $(1.43)$ \\
\hline \multirow[t]{2}{*}{ Above*underwriter } & $5.14 * * *$ & & & \\
\hline & $(6.91)$ & & & \\
\hline \multirow[t]{2}{*}{ VC*underwriter } & & $3.22 * * *$ & & \\
\hline & & $(3.31)$ & & \\
\hline \multirow[t]{2}{*}{ VC*small firm } & & & $-0.12 * *$ & \\
\hline & & & $(-2.34)$ & \\
\hline \multirow[t]{2}{*}{ BankDebt*small firm } & & & & -0.02 \\
\hline & & & & $(-0.45)$ \\
\hline R-square & 0.19 & 0.09 & 0.07 & 0.02 \\
\hline $\mathbf{N}$ & 289 & 289 & 289 & 147 \\
\hline
\end{tabular}

The numbers given in parentheses are t-statistics.

*indicates that the coefficient is significantly different from 0 at the $10 \%$ level.

** indicates that the coefficient is significantly different from 0 at the $5 \%$ level.

***indicates that the coefficient is significantly different from 0 at the $1 \%$ level. 
Table 8. Firms that maintain bank debt and those without bank debt vs. firms that repay bank debt

This table presents the difference in the means and medians of the variables between the two subsamples. Initial returns are calculated as the first-day closing price divided by the offering price minus one. Log of offering size indicates the natural log of the amount of money raised in the IPOs. Std of returns indicates the standard deviation of daily returns for 250 trading days from 20 days after the IPO. Assets, EPS (earnings per share), ROA (return on assets), Market-to-book, R\&D expenditure, total debt to assets, and long term debt to assets are measured on the first fiscal year ending date after IPO. Log of assets indicates natural log of book value of total assets. Market-to-book is the ratio of the book value of liabilities and preferred stock plus the market value of common stock divided by the book value of assets. R\&D expenditure is the ratio of research and development expenditure to net sales. Change in total debt-to-assets and change in long-term debt-to-assets are differences of the leverage ratios before and after the IPO.

\begin{tabular}{|c|c|c|c|c|c|c|c|c|}
\hline \multirow[b]{2}{*}{ Variable } & \multicolumn{3}{|c|}{ Firms that repay $=0$} & \multicolumn{3}{|c|}{ Firms that repay $=1$} & \multirow{2}{*}{$\begin{array}{c}\text { Mean } \\
\text { t-test }\end{array}$} & \multirow{2}{*}{$\begin{array}{c}\text { Median } \\
\text { t-test }\end{array}$} \\
\hline & Mean & Median & $\mathbf{N}$ & Mean & Median & $\mathbf{N}$ & & \\
\hline Initial return & 0.20 & 0.11 & 167 & 0.14 & 0.09 & 125 & $1.98 * *$ & -0.35 \\
\hline Log of offering size & 17.24 & 17.30 & 168 & 17.31 & 17.28 & 125 & -0.97 & -0.07 \\
\hline Log of assets & 17.81 & 17.75 & 139 & 18.06 & 17.87 & 105 & $-1.96 * *$ & 1.16 \\
\hline Std of returns (day 20-269) & 0.05 & 0.05 & 168 & 0.05 & 0.04 & 125 & $3.27 * * *$ & $-2.66 * * *$ \\
\hline EPS & -0.36 & 0.01 & 139 & -0.02 & 0.20 & 105 & $-2.27 * *$ & $2.33 * *$ \\
\hline ROA & -0.08 & 0.01 & 139 & -0.01 & 0.03 & 105 & $-2.41 * *$ & 1.42 \\
\hline Market-to-book & 3.86 & 3.38 & 139 & 3.09 & 2.61 & 105 & $2.72 * * *$ & $-2.97 * * *$ \\
\hline $\mathrm{R} \& \mathrm{D}$ expenditure & 1.49 & 0.12 & 134 & 0.09 & 0.00 & 104 & $2.29 * *$ & $-4.96 * * *$ \\
\hline Total debt-to-assets & 0.27 & 0.19 & 139 & 0.33 & 0.27 & 105 & $-2.32 * *$ & $2.97 * * *$ \\
\hline LT debt-to-assets & 0.07 & 0.01 & 139 & 0.11 & 0.02 & 105 & -1.65 & $2.97 * * *$ \\
\hline Change in total debt-to-assets & -0.42 & -0.27 & 137 & -0.42 & -0.39 & 105 & 0.01 & $-2.46 * *$ \\
\hline Change in LT debt-to-assets & -0.12 & -0.03 & 137 & -0.18 & -0.12 & 105 & 1.55 & $-4.79 * * *$ \\
\hline
\end{tabular}

** indicates that the means or medians of two subsamples are significantly different at the $5 \%$ level.

***indicates that the means or medians of two subsamples are significantly different at the $1 \%$ level. 


\section{CONCLUSION}

Extant theoretical models suggest that the role of financial intermediaries in reducing asymmetries of information, by the certifying and monitoring of firms, should reduce IPO underpricing; however, a recent analysis of IPO underpricing in the 1990s, indicates an opposite relationship between an underwriter's reputation and IPO underpricing and an ambiguous role of venture capitalists certifying the value of new issues. Additionally, previous literature documents a negative relationship between bank debt and underpricing in the 1980s, yet there are no recent studies addressing this relationship for IPOs in the 1990s. One possible explanation for the negative relationship between investment banks and underpricing could be the substitutive effect of venture capitalists and commercial banks. We could expect a stronger negative relationship between underwriter reputation and IPO underpricing when venture capitalists and commercial banks are not monitoring the issue, and a weaker relationship when several of these financial intermediaries jointly certify the issue.

Consistent with prior studies, we, using the data from the 2000s, find a positive correlation between underpricing and underwriter reputation when the offering price is set above the highest-estimated price among the prospectuses. When the sample is divided between venture- and non-venture-backed IPOs, the positive relationship between investment bank reputation and underpricing exists only for venture-capital-backed IPOs. No relationship is found between underwriter reputation and underpricing in the sample of non-venture-backed IPOs. Furthermore, we find that the partial-adjustment phenomenon, in the work of Carter et al. (2001), exists only for VC-backed IPOs with an offer price above the estimated price range.

Overall, we find that the presence of venture capital is not significantly related to the IPO, although we also find that a significantly negative relationship exists between the presence of venture capital and IPO underpricing for small firms, which have substantial ex ante uncertainty and the potential for considerable informational asymmetries. However, we do not find that the presence of bank debt reduces IPO underpricing; additionally, we do not find any substitutive or complementary relationships between banks and venture capitalists that affect IPO underpricing.

Interestingly, we find that firms repaying bank debt using proceeds from the IPO experience statistically lower underpricing. The firms that repay bank debt are larger, less risky, and have smaller growth opportunities, which may explain the lower underpricing.

\section{AUTHORS INFORMATION}

Kyojik Song, Sungkyunkwan University, College of Business, 53 Myeongnyun-dong 3-ga, Jongno-gu, Seoul 110745, Korea. E-mail: roysong@ @sku.edu

Young-Soo Choi, Sungkyunkwan University, College of Business, 53 Myeongnyun-dong 3-ga, Jongno-gu, Seoul 110-745, Korea. E-mail: sericys@skku.edu

Jong Eun Lee, Sungkyunkwan University, College of Business, 53 Myeongnyun-dong 3-ga, Jongno-gu, Seoul 110 745, Korea. E-mail: jelee2012@skku.edu (Corresponding author)

\section{DATA AVAILABILITY}

The data are publicly available from the sources identified in the paper.

\section{REFERENCES}

1. Akerlof, G. (1970). The market for lemons, qualitative uncertainty, and the market mechanism. Quarterly Journal of Economics, 84, 488-500.

2. Barry, C., Muscarella, J., \& Vetsuypens, M. (1990). The role of venture capital in the creation of public companies. Journal of Financial Economics, 27, 447-471. 
3. Beatty, R. \& Ritter, J. (1986). Investment banking, reputation, and the underpricing of initial public offerings, Journal of Financial Economics, 15, 213-232.

4. Benveniste, L. M. \& Spindt, P.A. (1989). How investment bankers determine the offer price and allocation of new issues. Journal of Financial Economics, 24, 343-361.

5. Booth, J. \& Smith, R. (1986). Capital raising, underpricing, and the certification hypothesis. Journal of Financial Economics, 15, 261-281.

6. Brav, A. \& Gompers, P.A. (1997). Myth or reality? The long-run underperformance of initial public offering: Evidence from venture and non-venture capital-backed companies. Journal of Finance, 52, 17911821.

7. Carter, R., Dark, F., \& Singh, A. (1998). Underwriter reputation, initial returns, and the long-run performance of IPO Stocks. Journal of Finance, 53, 285-311.

8. Carter, R. \& Manaster, S. (1990). Initial public offerings and underwriter reputation. Journal of Finance, 45, 1045-1068.

9. Carter, R., Cooney, J., Dark, F., \& Singh, A. (2001). The IPO partial-adjustment phenomenon and underwriter reputation. Working Paper.

10. DeAngelo, L.A. (1981). Auditor size and audit quality. Journal of Accounting \& Economics, 3(3), 183-200

11. Diamond, D. W. (1984). Financial intermediation and delegated monitoring. Review of Economic Studies, 51 (3), 393-414.

12. Gompers, P.A. (1995). Optimal investment, monitoring, and the staging of venture capital. The Journal of Finance, 50, 5, 1461-1489.

13. Hanley, K.W. (1993). The underpricing of initial public offerings and the partial adjustment phenomenon. Journal of Financial Economics, 34, 231-250.

14. Hull, R.M. \& Moellenberndt, R. (1994). Bank debt reduction announcements and negative signaling. Financial Management (Summer), 21-30.

15. James, C. (1987). Some evidence on the uniqueness of bank loans. Journal of Financial Economics, 19, 217-135.

16. Johnson, S.A. (1997). The effect of bank reputation on the value of bank loan agreements. Journal of Accounting, Auditing, and Finance, 83-100.

17. Lerner, J. (1994). Venture capitalists and the decision to go public. Journal of Financial Economics, 35 (3), 293-317.

18. Majluf, N. \& Myers, S. (1984). Corporate financing and investment decisions when firms have information that investors do not have. Journal of Financial Economics, 13, 187-221.

19. Megginson, W. \& Weiss, K. (1991). Venture capitalist certification in initial public offerings. The Journal of Finance, 46, 879-904.

20. Myers, S. (1977). Determinants of corporate borrowing. Journal of Financial Economics, 5, $147-175$.

21. Peterson, M. \& Rajan, R. (1994). The benefits of the firm creditor relationship. A study of small business financing. Journal of Finance, 40, 3-35.

22. Rajan, R. (1992). Insiders and outsiders: The choice between informed and arm's length debt. Journal of finance, 47, 4, 1367-1400.

23. Ramakrishnan, R. \& Thakor, A. (1984). Information reliability and the theory of financial intermediation. Review of Economic Studies, 15, 31-60.

24. Rock, K. (1986). Why new issues are underpriced. Journal of Financial Economics, 15, 187-212.

25. Slovin, M., Johnson, S., \& Glascock, J. (1992). Firm size and the information content of bank loan announcements. Journal of Banking and Finance, 16, 1057-1071.

26. Slovin, M.B. \& Young, J.E. (1990). Bank lending and initial public offerings. Journal of Banking and Finance, 12, 1-12.

27. Slovin, M., Sushka, M., \& Hudson, C. (1990). External monitoring and its effect on seasoned common stock issues. Journal of Accounting and Economics, 12, 397-417.

28. Sharpe, S. (1990). Asymmetric information, bank lending and implicit contracts: A stylized model of customer relationships. Journal of Finance, 45, 4, 1069-1087.

29. Titman, S. \& Trueman, B. (1986). Information quality and the valuation of new issues, Journal of Accounting and Economics, 8 (June), 159-172. 